\title{
DEIXIS USE IN “AL-QALB AL-JARÎH” SHORT STORY BY NAJIB KAILANI (A PRAGMATIC STUDY)
}

\author{
Sammad Hasibuan ${ }^{1}$ \\ ${ }^{1}$ Universitas Islam Negeri Sunan Kalijaga \\ ${ }^{1}$ Sammadhasibuan@gmail.com
}

\begin{abstract}
This study describe the types of deixis and their functions contained in the short story alQalb al-Jarîh by Najib Kailani. Through deixis, readers or listeners will be helped to know who, when, and where an utterance is carried out based on its context. In this study, the method used is descriptive-qualitative with a pragmatic approach. The object of the research is the short story al-Qalb al-Jarîh, while the research data in the form of words, phrases, and sentences identified contain elements of deixis. The results of the study prove that the short story of al-Qalb al-Jarîh by Najib Kailani contains various elements of deixis, including: person deixis, time deixis, place deixis, discourse deixis, and social deixis.
\end{abstract}

Keywords: Deixis; Short Story of al-Qalb al-Jarîh; Najib Kailani; Context; Pragmatic.

$$
\begin{aligned}
& \text { ملخص } \\
& \text { يتناول هذا البحث أنواع وأغراض الإشارية فن القصة القصيرة القلب الجريح تأليف نجيب الكليلاني، فإنه من خلال } \\
& \text { فهم الإشارية يستطيع القارئ أو السامع معرفة الشخص والزمن والمكان التى أجري بها الكالام المبني على السياق. }
\end{aligned}
$$

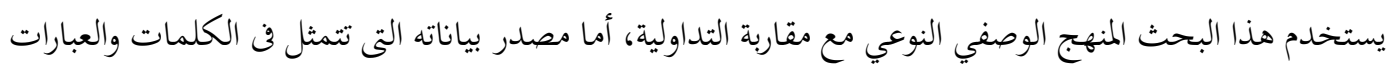

$$
\begin{aligned}
& \text { والجمل المحتوية على عناصر إشارية فهو القصة القصيرة القلب الجريح. وقد تدل نتائج البحث على أن في القصة } \\
& \text { القصيرة عناصر إشارية تشمل على إشارة الضمير، إشارة الزمن، إشارة المكان، إشارة الخطاب، إشارة المجتمع. } \\
& \text { الكلمات المفتاحية: الإشارسة، القصة القصيرة القلب الجريح، نجيب الكيلاني، السياق، التداولية. }
\end{aligned}
$$

\section{A. Pendahuluan}

Bahasa merupakan perangkat penyampai informasi antar sesama manusia. Peserta tutur yang menggunakan bahasa dalam sebuah interaksi komunikasi tidak boleh mengesampingkan situasi dan konteks yang melatarbelakanginya. Keduanya harus hadir dan saling melengkapi. Ibarat dua sisi mata uang, ada bahasa maka harus ada pula konteksnya. Ibrahim Fatha (Amara, 2019: 528) mengartikan konteks sebagai suasana tuturan, lingkup dan perangkat-perangkat lainnya. Konteks dapat diketahui secara eksplisit jika bahasa yang digunakan adalah bahasa lisan. Namun, berbeda kasusnya jika konteks yang ingin dicari dituangkan dalam bahasa teks atau tulisan. Salah memahami konteks dapat mengantarkan pada makna yang berlawanan dengan yang dimaksudkan oleh penulis atau petuturnya. Disiplin ilmu yang mengkaji bahasa dengan menitikberatkan pada konteks disebut dengan pragmatik. Bahasa Arab mempunyai banyak istilah untuk menyebut pragmatik, antara lain: pragmatique (البراغماتية), Contextielité (السياقية), Lintentionnalité (المقصودية), Pragmatisme (الذرائعية), dan é Situationnalit (المقامية) (Amara, 2019: 524).

Levinson (1983: 5-6) mendefinisikan pragmatik sebagai studi 
tentang penggunaan bahasa. Lebih lanjut, ia mengatakan bahwa pragmatik merupakan studi tentang prinsip-prinsip yang akan menjelaskan mengapa serangkaian kalimat tertentu menjadi anomali atau tidak mungkin diucapkan (the study of those principles that will account for why a certain set of sentences are anomalous, or not possible utterances). Definisi lainnya diungkapkan oleh Suleiman (2018: 156) yang menyebut bahwa pragmatik adalah kajian bahasa dalam penggunaannya atau komunikasi. Hal tersebut karena makna bukanlah sesuatu yang melekat pada kata-kata saja, penuturnya, ataupun pendengarnya, melainkan terwakili dalam sirkulasi bahasa antara penutur dan pendengar dalam konteks tertentu (fisik, sosial, linguistik) agar sampai pada makna yang melekat pada suatu tuturan. Lucian Sfez dalam (Blanchet, 2007: 19) mendefinisikan pragmatik sebagai studi atau spesialisasi dalam linguistik, yang menitikberatkan pada telaah penggunaan bahasa dalam sebuah komunikasi. Mas'ud Sahrawi (Benali, 2017: 223-224) menyebut pragmatik sebagai suatu aliran linguistik yang mengkaji tentang aktivitas hubungan bahasa dengan pemakainya, metode serta cara-cara menggunakan tanda-tanda bahasa dengan benar, konteks dan subkelas yang berbeda dengan sutau tuturan dilakukan. Selain itu, pragmatik menurut Mas'ud juga membahas faktor-faktor yang membuat suatu wacana menjadi pesan komunikatif yang jelas dan berhasil, dan juga membahas kegagalan dalam komunikasi dengan bahasa alami. Pendekatan pragmatik bertujuan untuk mengungkap makna sebuah tuturan melalui penutur, petutur dan konteks tuturan (Taufiq, 2018: 178). Selanjutnya, Pragmatik menurut Benkhouya (2019: 79) tidak semata-mata mengkaji unsur linguistik, tetapi juga mengkaji unsurunsur non-linguistik, meliputi situasi (أموقف أو المقام/(situation), situasi/konteks ( سلماق-context of

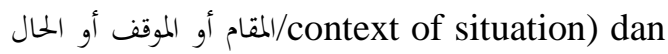
konteks (context/السياق).

$$
\text { Pada umumnya pragmatik }
$$

mempunyai empat bidang kajian, yaitu deiksis (deictics/الاشارية), presuposisi (الافتراض المسبق /presupposition), implikatur

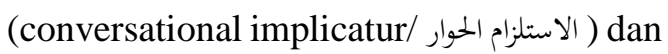
tindak tutur (speech acts/ الافعال الكلامية) (Suleiman, 2018: 160). Dalam referensi lain, disebutkan bahwa analisis wacana juga merupakan bidang dalam kajian pragmatik (Yuniarti, 2014: 226). Akan tetapi, yang akan dibahas dalam tulisan ini hanya bidang yang pertama, yakni dieksis.

Deiksis adalah nama yang diberikan untuk merujuk (to point) kepada sesuatu atau seseorang dari sudut pandang tertentu. Kata-kata deiktis seperti saya, kamu, ini, di sini dan sekarang. Rujukan kata "saya" bergantung pada dan bervariasi menurut konteks ujaran, yakni merujuk kepada sumber siapa yang mengatakan "saya". Kata-kata deiktik ini tidak biasa karena hanya dapat ditafsirkan dalam kaitannya dengan konteks kata-kata tersebut digunakan (Marcae, 2019: 33). Istilah deiksis yang berasal dari bahasa Yunani "deiktiktikos" digunakan dalam linguistik Barat modern untuk merujuk kepada elemen personal, ruang, dan waktu tertentu yang peristiwanya berdasarkan dimensi ruang-waktu. Terdapat tiga tipe utama deiksis, yaitu persona, ruang, dan waktu. Di samping itu, ada tambahan deiksis dalam bahasa Inggris dan bahasa lainnya (termasuk bahasa Arab), yaitu deiksis wacana dan deiksis sosial (Al Aubali, 2015: 118).

Stapleton melalui Nafi'ah, Rohmani Nur dan Toyyibah (2021: 61) mendefinisikan deiksis sebagai cara untuk membangun hubungan komunikasi antara dua mitra tutur atau lebih. Deiksis juga dianggap sebagai penghubung utama antara ruang, waktu, dan relasi antar subjek, sedangkan menurut Wijana (2015: 81) deiksis adalah satuan kebahasaan yang memiliki acuan yang berpindah-pindah. Misalnya, kata kemarin memiliki acuan yang berpindah-pindah berdasarkan pada kapan sebuah tuturan diucapkan. Deiksis dalam bahasa Arab disebut dengan AlIsyāriyyat. Mahmud Ahmad Nahlah dalam ('Abdunnabi, 2016: 456) mengatakan 
bahwa deiksis dalam semua bahasa berupa kata atau ungkapan yang sepenuhnya bergantung kepada konteks dimana katakata itu digunakan dan tidak dapat diproduksi atau diinterpretasikan secara independen. Abdullah (2015: 589) menyebut deiksis sebagai salah satu hal terpenting yang dilakukan oleh orangorang dengan ucapan. Setiap tindak tuturan, dapat dianggap berhasil jika mitra tutur mengetahui maksud dan mengerti tujuannya. Apabila penutur memiliki maksud, maka sudah seharusnya mitra tutur memiliki pengetahuan tentang ini (Amal \& Dalila, 2020: 120). Djadjasudarma (2017: 50) menyebut fenomena deiksis merupakan cara yang paling jelas untuk melukiskan hubungan antara bahasa dan konteks di dalam struktur bahasa itu sendiri. Oleh karena itu, mengetahui kata-kata deiksis dalam sebuah tuturan atau teks sangat diperlukan dan harus diperhatikan oleh mitra tutur atau pembaca.

Berikutnya, Levinson sendiri membedakan deiksis ke dalam lima jenis, yaitu: deiksis persona (الشخصية), deiksis waktu (الزمانية), deiksis tempat (المكانية), deiksis wacana (الحطابية) dan deiksis sosial (الاجتماعية). Louise Cumming dalam (Nafi'i, 2015: 14-15) mengklasifikasikan deiksis ke dalam dua kelompok; pertama, deiksis endoforis yang meliputi anaphora dan katafora. Kedua, deiksis eksoforis yang meliputi deiksis personal atau sosial, deiksis waktu, deiksis tempat, dan deiksis wacana. Adapun penjelasan mengenai masing-masing item tersebut akan dijelaskan sebagai berikut.

Pertama, Deiksis Persona ( الاشارات (الشخصية Deikis persona berkenaan dengan peranan peserta dalam sebuah tuturan, meliputi persona pertama sebagai pembicara, persona kedua sebagai lawan bicara, dan persona ketiga sebagai orang yang dibicarakan (Saifudin, 2019: 19). Ketiga jenis deiksis persona tersebut dalam bahasa Arab dikenal dengan istilah almutakallim, al-mukhātab dan al-ghāib. Dhamìr adalah istilah yang digunakan untuk menyebut pronomina atau kata ganti dalam bahasa Arab. Al-Ghalayainy dalam (Al Ghifari \& Supriadi, 2019:46) mengatakan bahwa dhamīr adalah suatu kata yang mengkiaskan mutakallim (P1), mukhātab (P2), dan ghāib (P3), misalnya: saya, kamu, dan dia (انا, انت, هو).

P1 untuk menunjukkan referen tunggal (انا) maupun plural (نزن) dan tidak mengenal jender. Dengan kata lain keduanya dapat digunakan dalam penunjukan laki-laki dan perempuan (Tumanggor et al., 2017: 26-28). Bertolak belakang dengan P1, P2 dan P3 mengenal jender, ada P2 khusus laki-laki dan untuk perempuan, misal انتِ, انتَ ,هو, هي. Selanjutnya, P2 dan P3 juga berurusan dengan jumlah pembicara atau yang dikenal dengan istilah mufrad, mutsanna dan jamak, seperti هي, هما, هم, انت, انتما, انتم (Deza Bi, 2015: 450). Oleh karena itu, tidak salah jika dikatakan bahwa deiksis persona versi bahasa Arab lebih komplit dibanding dengan deiksis persona dalam bahasa Indonesia maupun bahasa Inggris.

Ni'mah (1973: 113-117) membagi dhamīr ke dalam tiga jenis, yaitu terikat (متصل) baik dengan kata benda/noun (الاسم), kata kerja/verb (الفعل), maupun huruf الحرف) dan tidak terikat (منفصل). Satu jenis dhamīr yang perlu dijelaskan, yakni dhamīr mustatir. Dhamì ini tidak tampak pada tulisan dan hanya dapat ditemukan pada beberapa tempat, (1) fi'l mādhì mufrad (V1 tunggal), (2) fi'l mudhari' berawalan partikel ta, hamzah, dan nun, (3) fi'l amar tunggal. Untuk lebih jelasnya, dapat dilihat sebagai berikut:

Deiksis Persona pertama terikat, meliputi: ضربكن - ضكربن - ضربنا.

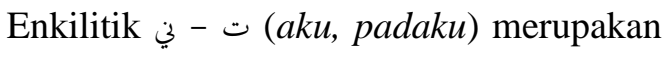
persona pertama tunggal terikat, sedangkan enklitik $ن$ (kami) merupakan bentuk deiksis persona pertama plural atau jamak. Selanjutnya, persona pertama tidak terikat, meliputi: اياي (aku - kepadaku) merupakan persona pertama untuk tunggal, sedangkan نحن - ايانا (kami) merupakan 
deiksis persona pertama plural atau jamak.

Kedua, Deiksis Waktu (الاشارات

(الزمانية. Deiksis waktu atau temporal deixis merupakan ungkapan atau kata-kata yang menunjukkan waktu dan telah terbatasi oleh konteks, meliputi tahun, bulan, ataupun hari (Musthafa, 2016: 66). Suleiman (2018: 161) mengatakan bahwa deiksi waktu adalah kalimat-kalimat yang menunjukkan waktu yang pastinya ditentukan oleh konteks dalam kaitannya dengan waktu suatu tuturan diucapkan. Jika waktu tuturan atau pusat dari tanda temporal/waktu tidak diketahui, maka hal ini tentu akan membuat pendengar atau pembaca menjadi bingung.

Deiksis waktu dalam bahasa Arab direpresentasikan dalam ism zaman, yaitu ساعة - يوم - اسبوع - شهر - سنة - صباح - مساء - سلاء ظهر - ليل - غدا - لحظة - برهة - مدة - فترة - حين - مئل

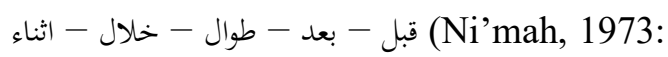

73). Meskipun demikian, pada dasarnya waktu atau masa dibagi ke dalam tiga, yakni masa lalu/lampau, masa sekarang dan masa akan datang. Hanya saja, beberapa bahasa memiliki kriteria yang lebih spesifik serta detail mengenai urutan waktu, seperti halnya bahasa Arab.

Ketiga, deiksis Tempat (الاشارات (اككانية). Deiksis tempat menurut Darsita (2015: 350) merujuk kepada pemberian tempat dalam sebuah tuturan, yang digunakan untuk merujuk kepada tempat terjadinya sebuah peristiwa tuturan, baik dekat (proksimal), agak jauh (semiproksimal), maupun yang jauh (distal). Bahasa Arab juga mengenal deiksis tempat berupa ism isyārah yang merujuk kepada tempat dekat (هذا- ذاك) maupun kepada tempat yang jauh (هنا - هناك). Selanjutnya kata keterangan tempat tersebut diperjelas oleh dharfal-makān, seperti وق - امام -تحت خل -. (Suleiman, 2018: 161). Ni'mah (1973: 73) menguraikan deiksis tempat وراء - قدَم - يمين - secara lengkap, meliputi

يسار - شمال - جنوب - شرق - غرب - وسط - قرب -

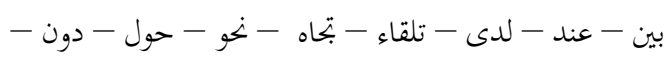

ميل - فرسخ - كيلوميتر.

Keempat, deiksis Wacana ( الاشارات

(الخطابية). Deiksis wacana menyangkut penggunaan ekspresi dalam beberapa ujaran untuk merujuk pada beberapa bagian dari wacana yang mengandung ucapan itu, termasuk ucapan itu sendiri (Nafi'ah \& Indah, 2021: 61). Suleiman (2018: 162) mengatakan bahwa ini termasuk salah satu karakteristik dari wacana, yang terepresentasikan dalam frasa yang disebutkan dalam sebuah teks dan referennya merujuk secara khusus kepada penutur atau penulis. Ungkapanungkapan demikian bisa jadi tampak ambigu, sebab referennya bisa merujuk kepada sesuatu yang letaknya bisa berada sebelum ataupun sesudah wacana. Ia menguraikan, beberapa ungkapan wacana ومهما يكن من امر, dalam bahasa Arab seperti . Wacana ini dapat juga meminjam indeks waktu maupun tempat untuk memunculkannya di dalam tuturan. Misalnya, untuk mengatakan (minggu yang lalu) الاسبوع الماضى, dapat الفصل الماضى من diganti dengan ungkapan الرأي السابق atau ( الكتاب

Darsita (2015: 350) menambahkan bahwa deiksis wacana umumnya merujuk kepada bagian-bagian tertentu dalam wacana yang telah diberikan. Dengan demikian, deiksis wacana berhubungan dengan penggunaan ungkapan dalam suatu ujaran yang mengacu pada bagian dari ujaran yang mengandung ungkapan.

Kelima, deiksis Sosial (الاشارات

(الاجتماعية). Fillmore dalam (Darsita, 2015: 350-351) menyatakan deiksis sosial adalah pemberian bentuk menurut perbedaan sosial yang mengacu pada peran para peserta, terutama dalam aspek sosial antara pembicara dan pendengar, atau pembicara dengan beberapa rujukan. Ia menambahkan, deiksis sosial ini berkaitan erat dengan partisipan. Oleh karena itu, di dalamnya tampak unsur honorik atau sebutan penghormatan dan etika bahasa. Suleiman menyebut deiksis sosial adalah 
ungkapan atau struktur yang merujuk kepada relasi sosial antara mitra tutur, baik hubungan resmi ataupun tidak resmi (teman atau suami-istri). Dalam konsep juga termasuk ungkapan memuliakan seseorang berdasarkan umurnya, posisinya, dan sebagainya.

Sebagaimana yang diuraikan di atas, objek kajian pragmatik tidak terbatas pada bahasa lisan saja, tetapi dapat juga digunakan untuk mengkaji bahasa tulisan. Hanya saja, interakasi komunikasi dalam bahasa tulisan tidak lagi terjalin antara penutur dan petutur, melainkan antara penulis, pembaca dan teks. Yang perlu digaris bawahi di sini, persamaan dari keduanya adalah tetap mencari makna berdasarkan konteks tuturan dalam sebuah teks.

Teks naratif merupakan salah satu dari jenis teks. Menurut Hugh Cory dalam (Zahara, 2011: 15) teks naratif adalah teks yang menceritakan sesuatu. Tujuannya pun bermacam-macam, seperti untuk menghibur, mendapatkan perhatian dari pembaca atau pendengar cerita, mendidik, memberitahu, dan mengembangkan imajinasi. Teks naratif umumnya berbentuk cerita, terdiri dari serangkaian peristiwa yang terjadi pada seorang tokoh. Teks naratif ditandai oleh adanya hubungan waktu. Peristiwa yang terdapat dalam teks naratif dapat disusun secara kronologis atau secara acak. Yang penting, hubungan waktu antar peristiwa seluruhnya memiliki kesatuan tindakan (Zaimar \& Harahap, 2015: 52-53).

Karya sastra, menurut Levinson dalam (Abualadas, 2019: 286) juga membedakan deiksis ke dalam beberapa tipe, meliputi deiksis waktu, deiksis tempat, dan deiksis persona. Cerpen sebagai salah satu jenis karya sastra juga merupakan contoh konkrit teks naratif serta termasuk objek dalam kajian pragmatik. Cerpen yang dimaksud di sini adalah cerpen karya Najib Al-Kailani yang berjudul Al-Qalb Al-Jarîh. Cerpen ini terdapat dalam antologi Hikâyât Al-Thabîb yang diterbitkan oleh Dar Al-Sahoh Li AlNasyr wa Al-Tawzi' pada tahun 2015. Cerpen tersebut mengandung berbagai jenis deiksis, sehingga menguraikan jenis- jenis deiksis yang muncul perlu dilakukan untuk mendapatkan makna yang dimaksud penulis sesuai dengan konteksnya. Jenis deiksis yang ditemukan dalam cerpen ini berupa deiksis persona, deiksis waktu, deiksis tempat, dan deiksis wacana. Kehadiran deiksis di dalam cerpen tidak semata-mata kosong dari konteks. Penggunaan deiksis-deiksis sebagai pengganti referen tentu tidak lepas dari usaha untuk mengoptimalkan struktur teks naratif. Maka dengan demikian, aplikasi dari pendekatan pragmatik, khususnya bidang deiksis dalam makalah ini diharapkan dapatkan menjadi sumbangsih keilmuan, umumnya dalam penelitian linguistik.

\section{B. Metode Penelitian}

Metode yang digunakan dalam penelitian ini adalah metode deskriptifkualitatif. Dalam mengumpulkan data, digunakan teknik simak dan catat. Data yang terkumpul berupa kata, frase, dan kalimat yang terindikasi sebagai deiksis. Selanjutnya, data yang ditemukan diolah secara kualitatif. Kemudian, dideskripsikan untuk memudahkan dalam menarik kesimpulan.

\section{Hasil dan Pembahasan}

Sebelum masuk ke dalam pembahasan, penulis merasa perlu menguraikan siapa saja partisipan tuturan, tempat atau lokasi dan waktu kejadian di dalam cerpen ini. Partisipan yang dibagi ke dalam dua jenis, yang aktif (yang sering selalu muncul) dan pasif muncul hanya beberapa kali. Adapun peserta tutur yang aktif, antara lain: (1) Narator cerpen sekaligus sebagai dokter penjara, (2) Abdul Jawwad, menjadi tokoh utama di dalam cerpen, (3) Teman-teman sepenjara Abdul Jawwad (salah satuya bernama Husein), mereka yang selalu penasaran dan bertanya-tanya apa yang terjadi dengan Abdul Jawwad, dan (4) Abbas yang merupakan teman dekat Abdul Jawwad yang tertarik kepada Salwa. Abbas juga merupakan seorang teman yang punya prilaku buruk, ia memanfaatkan rasa simpati Abdul Jawwad untuk meluruskan niatnya, yakni dengan menghasutnya untuk 
membenci atau bahkan membunuh saudari Abdul Jawwad, yaitu Salwa. Adapun peserta tutur yang pasif, yaitu (1) ayahnya Abdul Jawwad yang muncul satu adegan, (2) Mansur (anak sepupunya) hanya diceritakan di dalam cerpen, tapi tidak terlibat dalam dialog, dan (3) Salwa (saudarinya) yang munculnya juga sebentar. Ayah Abdul Jawwad dan Salwa hanya terlibat satu kali dalam dialog singkat. Tempat keseluruhan peristiwa berada di dalam penjara, tepatnya di kamar nomor dua belas. Selanjutnya, waktu yang disebutkan di dalam peristiwa ada yang masa lalu dan masa sekarang, ketika mereka bercerita di dalam penjara. Dengan mengetahui dan mengenal siapa, kapan, dan dimana cerpen ini diceritakan, maka akan mengantarkan pada pemahaman mengenai konteks yang dimaksud oleh pengarang, yakni Najib Kailani.

Berdasarkan penelitian yang dilakukan, dapat dikemukakan bahwa cerpen al-Qalb al-Jarîh mengandung unsur kelima jenis deiksis seperti yang diklasifikasikan oleh Levinson, yaitu deiksis persona, deiksis waktu, deiksis tempat, deiksis wacana dan deiksis sosial. Adapun uraiannya sebagai berikut:

Deiksis persona pertama tunggal digunakan penutur untuk menunjuk dirinya (laki-laki atau perempuan) sebagai referen yang dituju, sedangkan deiksis persona kedua digunakan untuk menunjuk lawan tutur/pembaca. Adapun persona pertama plural mengacu kepada kelompok dimana penutur menjadi bagiannya (Perkins, 1992: 101). Sementara itu, persona ketiga, baik tunggal maupun plural, mengacu kepada orang yang dibicarakan. Dalam artian, seseorang yang tidak terlibat di dalam tuturan, melainkan berada di luar tuturan.

Di dalam cerpen al-Qalb al-Jarih, ditemukan deiksis persona pertama tunggal dan plural atau jamak, sebagai berikut:

$$
\text { أنا لم اقتلك يا سلوى . . الشيطان هو الذي قتلك .. . . }
$$

"Saya tidak membunuhmu, Salwa ! Syaitan, dialah yang membunuhmu (Kailani, 2015: 65).
Konteksnya, ketika Abdul Jawwad sedang tidur pada suatu malam. Temanteman yang masih terjaga mendengarnya. Dalam tuturan ini, tampaklah bahwa Abdul Jawwad merasa menyesal telah membunuh saudarinya Salwa karena terhasut oleh ucapan temannya, Abbas. Jika saja ia tidak termakan dengan hasutan tersebut, tentu ia tidak akan mendekam di dalam sel malam itu dan tidak akan dihantui oleh rasa bersalah seumur hidup.

Deiksis P1 (ana) dalam kalimat tersebut engacu kepada Abdul Jawwad, sedangkan deiksis P2 bentuk terikat pada klausa sلïl (membunuh-mu) referennya adalah Salwa, yang merupakan saudari bdul Jawwad yang telah dibunuhnya.

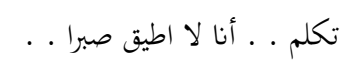

"Bicaralah, aku tidak sabar lagi (Kailani, 2015: 68).

Konteksnya, ketika Abdul Jawwad dan Abbas terlibat dalam sebuah dialog. Mulanya, Abbas tidak terus terang dan tampak basa-basi. Tetapi, Abdul Jawwad tidak sabar menunggu. Lantas ia mengatakan, "Katakanlah, aku tidak sabar menunggu”. تكلم (takallam) merupakan fi'il amar bentuk tunggal atau mufrad. Fungsi verba ini adalah ucapan yang meminta tindakan mitra tutur (Aulia \& Arifuddin, 2019: 56). Verba ini mengadung dhamir (kau: laki-laki/tunggal) berupa deiksis yang merujuk kepada Abbas, sebagai mitra tutur il, yang dalam tuturan ini adalah Abdul Jawwad sendiri.

$$
\text { فجأة سمعته يشهق باكيا وهو نائم }
$$

"Tiba-tiba, aku mendengarnya menangis tersedu-sedu, padahal dia sedang tertidur (Kailani, 2015: 65).

Konteksnya, ketika narator (dokter) dan teman-teman sepenjara sedang membicarakan Abdul Jawwad, tiba-tiba mereka terkejut mendengarnya sesenggukan, padahal saat itu ia sedang tidur. Deiksis (aku mendengar-nya) merujuk kepada narator sendiri yang pada saat itu sedang bercerita tentang siapakah Abdul Jawwad. 
Deiksis ini berupa deiksis P1, tunggal dan terikat.

$$
\text { وجنة ندعوك لقضاء الليلة معنا في زنزانة } 12 \text { ـ . وسنعد لك }
$$

"Kami mengajakmu menghabiskan malam ini bersama kami di dalam sel nomor 12, dan kami menyiapkan bagimu hidangan yang lezat (Kailani, 2015: 62).

Konteksnya, pada suatu malam salah seorang tahanan mendatangi narator (dokter) dan mengajaknya menghabiskan malam bersama mereka di kamar dua belas. Deiksis نحن (kami) P1, Plural dan bebas mengacu kepada para tahanan kamar dua belas. Sementara mitra tuturnya dapat dilihat pada klausa ندعوك (kami mengajak$\underline{\mathrm{mu}}$ ), yaitu dokter itu sendiri. Penggunaan deiksis P1 plural di sini bahwa para tahanan berharap besar jika dokter yang juga narator mau memenuhi keinginan mereka. Akan berbeda jika deiksis yang digunakan deiksis P1 tunggal, انا

Selain itu, ditemukan juga deiksis persona kedua, sebagai berikut:

$$
\begin{aligned}
& \text { قال: أنت هنا في مهمة رسمية اليللة . . ايها الاخ الطبيب } \\
& \text { السجين نريد رأيك في تلك الحالة المرضية. . }
\end{aligned}
$$

Ia berkata: "Kau di sini untuk sebuah misi yang resmi. Hai saudara dokter khusus tahanan, kami ingin pendapatmu terkait penyakit ini (Kailani, 2015: 64).

Pada kutipan ini, deiksis P2 أنت ( engkau laki-laki) mengacu kepada dokter penjara (narator). Sedangkan si penutur adalah seorang tahanan. Dialog ini terjadi di penjara, ketika si tahanan meminta pendapat dokter terkait masalah yang mereka hadapi tentang keanehan Abdul Jawwad.

$$
\text { تانا احبك أكثر من أي مخلوق . . . . انت روحي وحياتي ـ والله العظيم }
$$

"Kemarilah kekasihku, Salwa! engkau jiwaku dan hidupku. Demi Allah yang Maha Mulia, aku mencintaimu melebihi mahluk yang ada di muka bumi ini (Kailani, 2015: 65).

Kutipan ini menceritakan Abdul Jawwad. Deiksis P2 انت (dibaca kasrah: engkau/perempuan/tunggal) mengacu kepada Salwa, saudarinya sendiri. Sebenarnya, dalam kutipan ini sangat jelas disebutkan, sebab dalam gramatika atau ilmu Nahwu Arab, kata انت ini posisinya sebagai badal atau pengganti dari nama Salwa.

$$
\text { الحي كلها يعرف هذه الحقيقة، ويتندرون بها الا وانتم .. }
$$

"Sетиа penduduk kampung telah mengetahui kebenaran ini, dan mereka bergurau dengan itu, kecuali kalian (Kailani, 2015: 69).

Kutipan ini menceritakan dialog antara Abbas dan Abdul Jawwad. Deiksis P3/plural yang diwakili kata انتم (kalian/kamu sekeluarga) digunakan tidak hanya merujuk kepada Abdul Jawwad, tetapi juga keluarganya. Deiksis ini sengaja digunakan untuk mengglorifikasi kabar buruk Salwa yang sudah menyebar di kampung, sementara keluarganya belum tahu sama sekali.

Menurut Macrae (2019: 41) persona saya/aku dan kamu/engkau/anda merupakan inti dari inventarisasi deiktik, sebab keduanya tentu harus hadir sekaligus dalam tuturan, dimana keduanya berperan sebagai penutur dan mitra tutur. Sementara untuk persona ketiga, baik tunggal maupun plural, tidak akan pernah terlibat dalam pembicaraan. Biasanya, mereka hanya berada di luar sebagai objek yang dibicarakan.

Kemudian, ditemukan juga persona ketiga berbentuk tunggal dan plural, berikut ini:

$$
\begin{aligned}
& \text { ويحاولون في كل مرة أن يصالحوه ويعتذروا له, حتى ولو كان هو } \\
& \text { المخطئ. . افم جميعا اصحاب قضية رأى سجنوا بسببها }
\end{aligned}
$$

"Dan mereka berusaha setiap waktu untuk berbuat baik dan meminta maaf kepadanya, meskipun yang salah adalah dia. Sesungguhnya mereka semua memiliki 
kasus yang membuat mereka berada di penjara (Kailani, 2015: 62).

\section{Deiksis P3/tunggal dalam kutipan} di atas terletak pada kata هو, له (dia, padanya). Berdasarkan konteksnya, dia yang dimaksud di sini adalah Abdul Jawwad. Kutipan ini menceritakan bagaimana para tahanan lainnya menanggapi temperamennya yang tidak stabil. Bahkan, ketika yang membuat rusuh adalah Abdul Jawwad sendiri, tetapi malah mereka yang meminta maaf atas dasar simpati, kasihan, dan pengertian. Selain deiksis P3/tunggal, kutipan ini juga mengandung deiksis P3/Plural, yaitu pada kata أمم (mereka) yang referennya adalah para tahanan yang lain.

$$
\begin{aligned}
& \text { الواقع أخا كانت تتوق للزواج من ابن خالتها منصور كاتب } \\
& \text { الحسابات في مصلحة التيلفونات }
\end{aligned}
$$

"Faktanya, sesungguhnya ia sangat ingin menikah dengan sepupunya, Mansour, yang berprofesi sebagai petugas rekening di departemen telpon (Kailani, 2015: 67).

Kata خالتها (dia) dan (bibi-nya) merupakan jenis deiksis P3/tunggalperempuan/terikat. Jika dilihat dari konteksnya, yang dimaksud dia di sini adalah Salwa. Kutipan ini menceritakan Salwa yang tidak tertarik atau menyukai Abbas, melainkan ia lebih menyukai anak bibi-nya yang bernama Mansour. Bahkan, Salwa hanya ingin menikah dengan anak bibinya itu. Penolakan inilah yang membuat Abbas dendam dan kesal hingga akhirnya menghasut Abdul Jawwad.

$$
\text { كان يجادل أشخاصا بجهولين, ويحاورهم, لكننا نسمع الحوار من }
$$

"Ia sedang berdebat dengan orang-orang yang tidak diketahui, dan mereka berbicara. Akan tetapi, kami mendengar percakapan tersebut hanya dari satu sumber saya, ya tentu saja dia (Kailani, 2015: 64).

$$
\text { Kata o (mereka) pada ويحاورهم }
$$

adalah deiksis P3/laki-laki/plural sekaligus terikat. Berdasarkan konteksnya, deiksis tersebut mengacu kepada kata أشخاصا بجهولين (orang-orang yang tidak ketahui) yang berdebat dengan Abdul Jawwad ketika ia mengigau. Padahal, tahanan lainnya yang melihat peristiwa itu tidak melihat orang lain selain Abdul Jawwad. Deiksis lainnya pada kutipan ini adalah oن ovaitu, dia sendiri). Deiksis P3/tunggal/laki-laki merujuk kepada Abdul Jawwad. Hal tersebut dapat dipastikan karena memang dialah satu-satunya objek yang dibicarakan.

Berikutnya, dalam cerpen ini juga ditemukan deiksi waktu. Menurut Levinson (1983: 62) deksis waktu menyangkut penyandian titik-titik temporal (waktu) relatif dimana suatu ujaran diucapkan atau pesan tulisan dituliskan. Senada dengan itu, Mey dalam (Nadar, 2009: 56) menyebut ungkapan deiksis waktu menunjuk pada sesuatu keadaan dengan sudut pandang tertentu. اليوم Deiksis waktu yang dimaksud adalah (siang hari) muncul sebanyak delapan kali, الليل (malam hari) muncul sebanyak enam kali, lalu السابق (kemarin, yang lalu), بعد (setelah/sesudah), مساء (petang atau sore), dan احيانا (kadang-kadang atau jarang) masing-masing item muncul hanya satu kali. Deiksis waktu yang digunakan dalam cerpen al-Qalb al-Jarih dapat dilihat sebagai berikut:

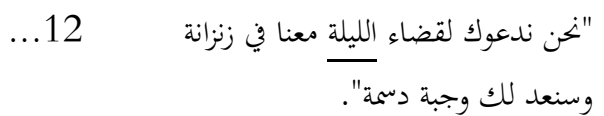

"Kami mengajakmu untuk menghabiskan malam ini bersama kami di kamar 12 . . dan kami akan menyiapkan makanan lezat untukmu (Kailani, 2015: 62).

Konteksnya, ketika teman-teman Abdul Jawwad yang di penjara mengajak narator (dokter) untuk menghabiskan waktu malam bersama mereka di kamar dua belas. Waktu yang pilih adalah malam, yang dilihat pada penggunaan deiksis 
waktu pada kata الليلة (malam ini). Dari konteksnya, tuturan ini terjadi pada suatu ketika ketika salah seorang mereka menemui dokter untuk menyampaikan maksud dan tujuan mereka. Adapun waktu yang disepakati adalah malam hari itu.

$$
\text { وان الناس يتهامسون بعاره . . كيف يرفع رأسه بعد اليوم }
$$

"Dan orang-orang itu membisikkan rasa malunya, bagaimana ia dapat menegakkan kepalanya setelah hari ini (Kailani, 2015: 68).

Konteksnya, setelah Abdul Jawwad mendengar hasutan Abbas, ia merasa terpukul dan begitu malu. Deiksis waktu pada kata اليوم (hari ini) mengisyaratkan bahwa Abbas menghasutnya pada hari itu. Menyadari hasutan tersebut akan membuat malu baginya dan juga keluarganya, maka ia sebagai seorang yang terhormat tidak akan berani menegakkan kepalanya di hadapan orang-orang banyak. Dengan demikian, jika sebelumnya Abdul Jawwad tidak merasa malu, maka sejak Abbad menghasutnya hari itu, maka seketika berubah menjadi malu dan geram.

"Dalam $\quad$ konsep inilah, mereka menyepakati konsep yang sebelumnya (Kailani, 2015: 62).

Konteksnya, teman-teman Abdul Jawwad di penjara dan telah mengerti perilaku anehnya, jika suatu waktu Abdul Jawwad marah, maka mereka akan mengalah dan memahami. Mereka tahu keanehan itu dari sebelumnya, dan jika itu terjadi, maka mereka akan melihat apa yang terjadi pada waktu السابق (sebelumnya atau yang telah lalu).

$$
\begin{aligned}
& \text { والتقى بعبد الجواد ذات مساء . . صحبه الى مكان بعيد . . } \\
& \text { قدم له عددا من اكواب النبيذ والسجائر }
\end{aligned}
$$

"Dan ia bertemu dengan Abdul Jawwad pada suatu sore, ia menemaninya ke suatu tempat yang jauh, ia menawarkan kepadanya gelas-gelas berisi anggur dan rokok (Kailani, 2015: 67).

Konteksnya, kutipan di atas menceritakan pertemuan Abdul Jawwad dengan Abbas pada suatu sore. Kapan sorenya, tidak dijelaskan secara detail karena menggunakan isim nakirah (makna umum). Yang jelas, waktu mereka bertemu terjadi pada suatu sore (ذات مساء) bukan malam, siang ataupun pagi.

$$
\text { وبعد أن انتهى الصديق السجين من قصة عبد الجواد عدت أنظر }
$$

"Dan setelah teman sepenjara itu selesai menceritakan kisah tentang Abdul Jawwad, aku kembali melihat kepada lakilaki yang sedang tertidur itu (Kailani, 2015: 70).

Konteksnya, ketika seorang tahanan telah selesai menceritakan kisah haru seorang Abdul Jawwad, narator (dokter) merasa iba dan seketika memandang ke arah laki-laki menyedihkan yang sedang tertidur. Di dalam tuturan, yang terlibat dalam dialog adalah seorang tahanan dan dokter, sedangkan yang menjadi objek adalah Abdul Jawwad. Dalam hal ini, narator melihat kepada Abdul Jawwad setelah (بعد) cerita selesai.

$$
\text { تكالبت عليه }
$$

"Dan terkadang kami melihatnya duduk diam dan sedih, seolah-seolah kekhawatiran seluruh dunia berkolusi dengannya (Kailani, 2015: 61).

Kutipan ini menceritakan bagaimana keadaan Abdul Jawwad di mata para tahanan lainnya. Kadang, ia sangat gembira dan kadang pula ia sangat sedih, diam, dan terduduk, seolah-olah kegelisahan seluruh dunia menghujam dirinya. Deiksis yang digunakan di sini adalah deiksis waktu, yaitu واحيانا yang berarti tidak selalu, tapi hanya sesekali.

Selanjutnya, di dalam cerpen juga ditemukan deiksis tempat. Deiksis tempat mengacu kepada referen tempat tuturan dilaksanakan. Menurut Levinson (1983:62) 
mayoritas bahasa hanya membedakan dua tempat, yakni yang dekat (proximal) dan yang jauh (distal). Deiksis tempat yang تحت ditemukan di dalam cerpen ini adalah (di bawah), بن (di sini), بين (di antara), dan فوق (di atas), keempat deiksis tempat tersebut dapat dilihat pada kutipan berikut:

$$
\begin{aligned}
& \text { وقضينا تلك الليلة سهرة متعة تحت الظلام الدامس اذلم يكن } \\
& \text { يسمح باضاءة الزنازين في تلك اليلة. }
\end{aligned}
$$

"Dan kami menghabiskan malam yang menyenangkan itu di bawah kegelapan total, karena seluruh sel pada malam itu dilarang untuk dinyalakan (Kailani, 2015: 63).

Deiksis pada kutipan ini adalah kata تحت (di bawah). Artinya, mereka menghabiskan malam di bawah kegelapan yang total, sebab para tahanan ketika malam hari dilarang untuk menghidupkan lampu.

$$
\begin{aligned}
& \text { قال: أنت هنا في مهمة رسمية اليللة . . ايها الاخ الطبيب } \\
& \text { السجين نريد رأيك في تلك الحالة المرضية. . }
\end{aligned}
$$

Ia berkata: "Kau di sini untuk sebuah misi yang resmi. Hai saudara dokter khusus tahanan, kami ingin pendapatmu terkait penyakit ini (Kailani, 2015: 64).

Deiksis tempat pada dialog ini adalah kata is (di sini) yang berarti di dalam penjara kamar dua belas. Deiksis ini dalam bahasa Arab dikenal dengan istilah isim isyarah, yang bermakna tunjukan kepada yang dekat.

$$
\text { ومن أجل الحب القديم يربط بيني وبينك برباطه المقدس. . }
$$

"Dan demi cinta lama yang mengikatmu dan aku dengan ikatan sucinya.. (Kailani, 2015: 64).

Kata بيني وبينك (antaraku dan kamu) tidak merujuk kepada referen secara fisik, melainkan kepada hubungan sosial, dengan kata lain hubungan persahabatan. Sudah bukan menjadi rahasia lagi bagi khalayak umum bahwa cinta tidak memiliki bentuk, tetapi bisa dirasakan secara emosional dan sosial.

$$
\text { وأنه يسقط من فوق قمة جبل الى واد سحيق. . }
$$

"Dan sesuunguhnya ia terjatuh dari atas puncak gunung ke lembah yang dalam.. (Kailani, 2015: 68).

Deiksis tempat فوق (di atas) menjelaskan bahwa Abdul Jawwad seolah terjatuh dari atas atau puncak ke gunung. Hal ini terjadi setelah ia mendengar pernyataan Abbas dan terhasut karenanya. Ia yang awalnya merasa mulia, tiba-tiba merasa hina.

Deiksis berikutnya yang didapatkan dalam cerpen adalah deiksis wacana. Macrae (2019: 35) mengatakan bahwa deiksis wacana adalah bahasa yang menunjuk pada bagian atau aspek konteks wacana atau koteks dimana bahasa itu digunakan. Suleiman (2018: 162) menambahkan, deiksis wacana umumnya dapat meminjam deiksis waktu atau pun deiksis tempat untuk membangun wacana. Deiksis wacana dalam cerpen dapat dilihat pada kutipan berikut:

$$
\text { وهو اذا غضب أو تشاجر تدفقت كلمات السخط والاحتجاج }
$$

"Dan jika dia marah atau bertengkar, maka keluarlah kata-kata kemarahan dan protes terang-terangan, seolah-olah dia seorang pemberontak (Kailani, 2015: 61).

Kutipan ini melukiskan bagaimana kondisi batin Abdul Jawwad selama di penjara. Selain sering mengigau, ia juga menjadi sosok yang temperamental. Bahkan, ketika marah ia tak sungkan meluapkan kata-kata hinaan dan protes. Para tahanan melihatnya seolah-olah sosok demonstran.

$$
\begin{aligned}
& \text { وارتفع صوته عاليا وهو يصرخ سلوى . . سلوى . . كان صوته }
\end{aligned}
$$

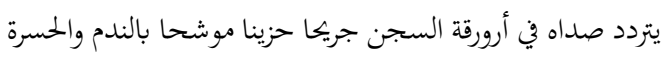

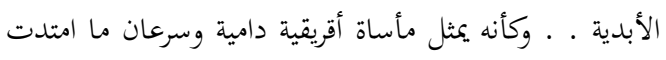

$$
\begin{aligned}
& \text { اليه يد أحد الاصدقاء وهزه برفق. . . ل }
\end{aligned}
$$

"Dan suaranya makin meninggi dan ia 
berteriak, Salwa! Salwa! Suaranya bergema di koridor penjara, terluka dan sedih, diwarnai dengan penyesalan patah hati abadi, dan seolah-olah itu adalah representasi dari drama tragedi berdarah Yunani, dan segera salah seorang teman mengulurkan tangan kepadanya dan membangunkannya dengan lembut (Kailani, 2015: 65).

Kutipan ini menggambarkan bagaimana Abdul Jawwad ketika tidur dan kerap mengigau. Salah satunya adalah ketika ia mengigau meminta maaf kepada Salwa, suaranya terdengar di seluruh koridor. Sampai-sampai, para tahanan merasa penyesalan itu tak ubahnya drama tragedi berdarah Yunani.

Deiksis yang terakhir adalah deiksis sosial. Menurut Suleiman (2018: 162) deiksis sosial adalah ungkapan atau struktur yang mengacu kepada hubungan partisipan dalam sebuah tuturan, baik hubungan yang resmi seperti keluarga, ataupun yang tidak resmi seperti hubungan pertemanan. Deiksis sosial tersebut dapat dilihat pada kutipan di bawah ini:

$$
\begin{aligned}
& \text { عبد الجواد أنت أخي وحبيبي } \\
& \text { رد عبد الجواد في ثقة : } \\
& \text { أعلم ذلك يقينا }
\end{aligned}
$$

"Abdul Jawwad, engkau saudaraku dan kekasihku".

Abdul Jawwad menjawab dengan percaya diri: Saya tahu itu pastinya (Kailani, 2015: 67).

Kutipan ini mengadung deiksis sosial, dimana dalam dialog ditampilkan bagaimana persahabatan antara Abdul Jawwad dan Abbas. Selain menyebut nama, kata أنت (engkau) memperjelas kedekatan partisipan tuturan. Nada yang dilukiskan dalam tuturan pun adalah nada yang sopan dan penuh penghargaan.

$$
\begin{aligned}
& \text { تعالي ياحسبيتي . . سلوى . . أنت روحي وحياتي . . و الله العظيم }
\end{aligned}
$$

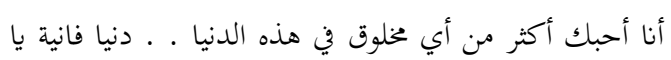

$$
\begin{aligned}
& \text { سلوى }
\end{aligned}
$$

"Kemari, Kekasihku, Salwa, engkau jiwaku dan hidupku. Demi Tuhan yang mulia, aku mencintaimu melebihi semua mahluk yang ada di muka bumi ini. Dunia ini tidak kekal, Salwa (Kailani, 2015: 65).

Kutipan ini juga sarat akan deiksis sosial. Partisipannya adalah dua bersaudara, Abdul Jawwad dan Salwa. Suatu keniscayaan dalam hidup untuk menyayangi dan mencintai saudara. Setidaknya, hubungan darah inilah yang coba digambarkan di dalam tuturan tersebut.

\section{Kesimpulan}

Berdasarkan uraian di atas dapat disimpulkan bahwa mengetahui dan memahami kehadiran deiksis berdasarkan konteksnya dalam tuturan akan memudahkan mitra tutur atau pembaca mengerti, siapa, kapan, di mana tuturan tersebut dilaksanakan. Demikian pula cerpen al-Qalb al-Jarîh, yaitu cerpen yang memuat secara lengkap unsur kelima deiksis, meliputi: deiksis persona (pertama: aku, -ku dan kami atau kita, kedua: engkau, kau, anda, atau kalian laki-laki maupun perempuan, dan ketiga: dia, ia, mereka laki-laki maupun perempuan), deiksis waktu, deiksis tempat, deiksis wacana dan deiksis sosial.

\section{Daftar Pustaka}

'Abdunnabi, S. K. (2016). Al-Isyâriyyât Fi Al-Lughat Al-Pârisiyyah (Dirâsat Tathbiqiyyah 'Alâ Al-Nash AlPârisiy Li Kalîlah Wa Dimnah). Hauliyât Kulliyat Al-Âdâb Jâmi'atu 'Ain Syam, 44(2).

Abualadas, O. (2019). Person Deixis and Point of View in English-Arabic Fiction Translation: A Trend towards Repositioning the Narrator, Characters and Readers. International Journal of ArabicEnglish Studies (IJAES), 19(2).

Al Aubali, F. A. (2015). Deixis in Arabic and English: A Contrastive Approach. International Journal of Applied Linguistics \& English Literature, 4(4). 
Al Ghifari, F., \& Supriadi, D. (2019). Bentuk Deiksis Persona Kedua Dalam Novel 'Asyakir Qaus Quzh Karya Sakinah Ibrahim Dan Novel Laskar Pelangi Karya Andrea Hirata (Kajian Pragmatik). Hijai - Journal on Arabic Language and Literature, 2(2).

Amal, M., \& Dalila, M. (2020). Al-Bu'da Al-Tadawuliy Li Al-Isyariyaat AlSyakhsiyyat Fi Maqamaat Al-Hariry (Al-Dhamair Anmudzujan. Majallat Isykalat Fi Al-Lughah Al-'Arabiyyah, 9(4).

Amara, F. T. (2019). Al-Lisâniyyât AlTadâwuliyah Al-Mafâhîm Wa AlMushtalahât. Djoussour El-maaréfa, 5(3), 524-535.

Aulia, J., \& Arifuddin. (2019). Tindah Tutur Imperatif (Kalam al-Amr) Dalam Teks Drama A's-Sulthan AlChair Karya Taufiq Al-Chakim (Analisis Pragmatik). Jurnal CMES, XII(1).

Benali, K. (2017). Al-Tadâwuliyah Muqaddimah 'Ammah. Majallat Ittihâd Al-Jami'ât Al- 'Arabiy Li AlÂdâbi, 14(1).

BenKhouya, R. (2019). Al-Tamazharât AlTadâwuliyah Fi Al-Balâgah Al'Arabiyyat. Djoussour El-maaréfa, 5(1), 72-93.

Blanchet, P. (2007). Al-Tadawuliyah Min Austin Ila Goffman. Terj: Saber Habacha. Suria: Dar Al-Hiwar Li AlNasyar wa Al-Tauzi'.

Darsita. (2015). Deiksis Dalam Kumpulan Cerpen Al-Kabuus: Tinjauan Sosiopragmatik. Al-Turas, XXI(2).

Deza Bi, D. J. H. (2015). Al-Ta'syir wa AlTaba'ud Baina Al-Qudama wa AlMuhadditsin Muqarabah Tadawuliyah. Majallah Jami'ah Zakho, 3(3), 447-471.

Djadjasudarma, T. F. (2017). Wacana dan Pragmatik. Bandung: PT Refika Aditama.

Kailani, N. (2015). Hikayat al-Thabib.
Mesir: Dar el Shahah.

Levinson, S. C. (1983). Pragmatics. Cambrideg; New York: Cambridge University Press.

Marcae, A. (2019). Discourse Deixis in Metafiction The Language of Metanarration, Metalepsis and Disnarration. New York: Routledge.

Nadar, F. X. (2009). Pragmatik dan Penelitian Pragmatik. Yogyakarta: Graha Ilmu.

Nafi'ah, A. U., \& Indah, R. N. T. (2021). English Deixis In Picture Storybooks For Children. Wanastra: Jurnal Bahasa dan Sastra, 13(1).

Nafi'i, W. (2015). Makna Dalam Wacana. Arabia, 7(1).

Ni'mah, F. (1973). Mulakhas Qawa'id AlLughah Al-'Arabiyyah. Damaskus: Dar Al-Hikmah.

Perkins, R. D. (1992). Deixis, Grammar and Culture. Amsterdam: Benjamins.

Saifudin, A. (2019). Deiksis Bahasa Jepang dalam Studi Linguistik Pragmatik. Japanese Research on Linguistics, Literature, and Culture, 2(1), 16-35.

Subhi Abdillah, E. (2015). Al-Bahts fi Akhtâi Thulbah Al-Jami'ah Al'Irâqiyyah Muta'allimy Al-Lughah Al-Inkiliziyyah bi Wasfihâ Lughat Ajnibiyyat fi Isti'mâl al-Ta'âbîr alIsyâriyyah Fi Masrahiyyat Hamlet Li Shakespeare. Majallah Kulliyat AlTarbiyyah, 1(19), 553-583.

Suleiman, M. J. E.-D. (2018). Al-Tadris Al-Tadawuliyah Li Maharat AlTawashul Asy-Syafawiy Fi Baramaj Ta'lim Al-Lughah Al'Arabiyah Li Al-Nathiqina Bigairiha. Al-Majallat Al-Dauliyyah Li Al-Buhust Fi Al'Ulum Al-Tarbawiyah, 1(3).

Taufiq, W. (2018). Metodologi Penelitian Bahasa Arab. Bandung: PT Refika Aditama.

Tumanggor, I., Pujiati, \& Nasution, K. (2017). Deiksis Persona Dalam AlQur'an Surah Al-Kahfi. Jurnal 
Waraqat, 2(2), 20-41.

Wijana, I. D. P. (2015). Pengantar Semantik Bahasa Indonesia. Yogyakarta: Pustaka Pelajar; Program Studi S2 Linguistik Fakultas Ilmu Budaya, UGM.

Yuniarti, N. (2014). Implikatur Percakapan Dalam Percakapan Humor. Jurnal Pendidikan Bahasa, 3(2).
Zahara, R. S. (2011). Deiksis dan Pemahaman Teks Narasi Bahasa Arab (Telaah Novel Al-Karnak Karya Najib Mahfuz). Tangerang Selatan: LSIP (Lembaga Studi Islam Progresif).

Zaimar, O. K. S., \& Harahap, A. B. (2015). Teori Wacana. Jakarta: Penaku. 